\title{
Kokemuksia valkuaiskasvien viljelystä ja käytöstä nautojen ruokinnassa
}

\author{
Katariina Manni
}

\author{
Hämeen ammattikorkeakoulu, Maaseutuelinkeinot, Mustialantie 105, 31310 Mustiala, \\ katariina.manni@hamk.fi
}

\section{Tiivistelmä}

Suomessa viljeltävissä valkuaiskasveissa on paljon mahdollisuuksia valkuaisomavaraisuuden lisäämiseksi nautojen ruokinnassa. Valinnanvaraa löytyy niin kasvivalikoimasta kuin korjuumenetelmistäkin. Hyviä kotoisia valkuaisen lähteitä ovat $\mathrm{mm}$. apilat, sinimailanen, virnat, herne, härkäpapu, lupiinit sekä rypsi ja rapsi. Osa näistä voidaan korjata puimalla, osa säilörehuksi ja osa kummalla menetelmällä tahansa. Hämeen ammattikorkeakoulussa tehtiin vuosien 2014 ja 2015 aikana neljä opinnäytetyötä joissa selvitettiin kokemuksia valkuaiskasvien viljelystä ja käytöstä nautojen ruokinnassa. Työt toteutettiin viljelijähaastatteluina Etelä-Suomen alueella. Kohderyhmänä oli sekä kasvinviljelytiloja että maidon- ja naudanlihantuottajia. Vastausten perusteella valkuaiskasveista saatavat hyödyt niin viljelyssä kuin nautojen ruokinnassa olivat moninaiset. Valkuaiskasvit toivat monipuolisuutta viljelykiertoihin ja maan rakenteen todettiin parantuneen. Ne olivat maittavia rehuja ja sekä syönnin että tuotosten lisääntymistä havaittiin. Hyvänä asiana pidettiin myös niiden monipuolisuutta niin rehukäytössä kuin korjuussakin. Haastatteluissa kävi ilmi, että valkuaiskasvien viljelyn kannustimena oli erityisesti säästöt ostolannoite- ja rehukustannuksissa. Typpeä sitovia palkokasveja viljelemällä oli voitu vähentää ostolannoitteiden käyttöä. Kotoisilla valkuaisrehuilla puolestaan voitiin korvata ostovalkuaisrehuja. Vaikka viljelijät olivat pääosin tyytyväisiä valkuaiskasvien viljelyyn ja rehukäyttöön, haasteitakin löytyi. Erityisesti kasvien viljelyvarmuuteen ja satoisuuteen toivottiin parannusta esimerkiksi lajikevalikoimaa lisäämällä. Rikkakasvien torjuntaan sopivia kasvinsuojeluaineita oli niukasti saatavilla. Osalla valkuaiskasveista, erityisesti härkäpavulla, pitkä kasvukausi ja sateiset korjuukelit puinnin ja kuivauksen kannalta koettiin viljelyn riskinä. Toisaalta mahdollisuus korjata härkäpapu säilörehuksi pienensi korjuuseen liittyvää riskiä. Herneen viljelyssä haasteena oli sen lakoutumisherkkyys. Tosin tätä voitiin vähentää viljelemällä hernettä seoskasvustona viljan kanssa. Tällöin vilja toimii herneen tukikasvina ja ehkäisee lakoutumista. Ruokinnassa valkuaiskasvien käytön haasteena mainittiin melko vähäinen kotimaisen tutkimustiedon saatavuus. Erityisesti eri valkuaisrehujen käyttömääristä ruokinnassa ja vaikutuksista tuotantotuloksiin kaivattiin lisätietoa. Viljelijöitä tulisi myös kannustaa teettämään nykyistä enemmän rehuanalyysejä kotoisista valkuaisrehuista niiden käytön optimoimiseksi ruokinnassa. Valkuaiskasvien viljely nähtiin mahdollisuutena lisätä tilojen välistä yhteistyötä. Kaikki karjatilalliset eivät viljele valkuaiskasveja omalla tilallaan tai viljely on riittämätöntä. Kasvinviljelytiloilla puolestaan valkuaiskasvit ovat hyvä viljojen välikasvi. Yhteistyölle karja- ja viljatilojen välillä on siis tilausta. Kotoisissa valkuaiskasveissa on paljon mahdollisuuksia. Nyt tarvitaankin toimenpiteitä, jotta niiden viljely ja käyttö lisääntyisivät. Sen lisäksi että tarvitaan lisää tietoa, kokemusten vaihtoa ja tilojen välistä yhteistyötä, tarvitaan myös oikeanlaista asennetta ja tahtoa, jotta valkuaisomavaraisuus saadaan nousuun.

Asiasanat: valkuaisomavaraisuus, valkuaiskasvi, kasvinviljely, nauta, ruokinta 


\section{Johdanto}

Suomen valkuaistäydennysrehujen omavaraisuusaste on vain noin $15 \%$, eli tuontivalkuaisrehujen osuus on merkittävä. Suurin osa tuontivalkuaisesta on rypsiä, rapsia ja soijaa (Kaukovirta-Norja ym. 2015). Erityisen kriittiseksi asiaksi valkuaisomavaraisuus nousee luomutuotannossa, koska teollinen luomuvalkuaisrehuvalikoima on hyvin rajallinen.

Valkuaisomavaraisuuden lisäämisestä saatavat hyödyt ovat moninaiset, ja niiden vaikutukset ovat merkityksellisiä niin valtakunnallisesti, alueellisesti kuin yksittäisillä maatiloillakin. Valkuaiskasvien viljelyä lisäämällä voidaan mm. pienentää tuontirehuihin liittyviä riskejä, lisätä ruokaturvaa, parantaa huoltovarmuutta, kääntää rahavirtoja kotimaiseen tuotantoon ja kulutukseen sekä lisätä lopputuotteiden kotimaisuusastetta (Kaukovirta-Norja ym. 2015). Tilatasolla tarkasteltuna valkuaiskasvien viljely mm. monipuolistaa peltojen käyttöä ja viljelykiertoa, parantaa maan viljelyominaisuuksia, tuo joustoa rehujen korjuuaikoihin sekä vähentää ostolannoitteiden ja -rehujen tarvetta.

On todettu, että valkuaiskasvien viljelyn kilpailukyvyn parantuminen on edellytys, jotta niiden viljely ja käyttö kotieläinten ruokinnassa lisääntyisi. Keskeisinä tekijöinä tässä on viljelykustannusten pienentäminen, satotasojen nosto ja kasvien viljelyvarmuuden lisääminen (Huusela-Veistola ym. 2012, Peltonen-Sainio 2013). Myös lopputuotteen hinta sekä myynti- että ostorehuna on ratkaisevaa. Lisäksi tarvitaan uutta tutkimustietoa, osaamisen lisäämistä ja hyviä käytännön esimerkkejä valkuaiskasvien viljelystä ja käytöstä ruokinnassa. Myös tilojen välistä yhteistyötä tarvitaan, jotta kysyntä ja tarjonta kohtaisivat nykyistä paremmin (Peltonen-Sainio 2013).

Suomessa viljeltävissä valkuaiskasveissa on paljon mahdollisuuksia valkuaisomavaraisuuden lisäämiseksi (Stoddard ym. 2010, Peltonen-Sainio 2013). Valinnanvaraa löytyy niin kasvivalikoimasta kuin korjuumenetelmistäkin. Hyviä kotoisia valkuaisen lähteitä ovat mm. apilat, sinimailanen, virnat, herne, härkäpapu, lupiinit sekä rypsi ja rapsi. Osa näistä voidaan korjata puimalla, osa säilörehuksi ja osa kummalla menetelmällä tahansa.

\section{Aineisto ja menetelmät}

Tämä yhteenveto perustuu Hämeen ammattikorkeakoulussa vuosien 2014 ja 2015 aikana tehtyihin opinnäytetöihin, joissa selvitettiin kotimaisten valkuaiskasvien viljelykokemuksia ja käyttöä nautojen ruokinnassa. Näistä opinnäytetöistä Lehtisen (2014) työssä selvitettiin härkäpavun ja Mikkolan (2014) työssä herneen käyttöä lypsylehmien ruokinnassa. Huuskosen (2014) työssä tarkasteltiin valkuaisrehujen käyttöä lihanautojen ruokinnassa ja Kasvala (2015) selvitti työssään sinimailasen viljelykokemuksia ja käyttöä lypsylehmien ruokinnassa.

Aineistot kerättiin viljelijähaastatteluina Hämeen, Satakunnan, Uudenmaan ja Varsinais-Suomen alueilta. Kohderyhmänä oli sekä kasvinviljelytiloja että maidon- ja naudanlihantuottajia. Osa tiloista viljeli valkuaiskasveja ja käytti niitä nautojen ruokinnassa, osa vain viljeli ja osa käytti ruokinnassa ostaen valkuaisrehuja toisilta viljelijöiltä. Haastateltuja tiloja oli yhteensä 28. Suurin osa tiloista oli tavanomaisessa tuotannossa, mutta mukana oli myös luomutiloja.

\section{Kokemuksia valkuaiskasvien viljelystä}

Palkokasvien typensidontakykyä ja siitä saatavia säästöjä ostolannoitekustannuksissa pidettiin yhtenä merkittävänä hyötynä niiden viljelyssä. Ostolannoitteiden käytön väheneminen perustui sekä palkokasvien typensidontakykyyn että niiden hyvään esikasviarvoon. Typensidontakyvyn johdosta palkokasveille annettiin kylvön yhteydessä vain starttilannoite n. $10-50 \mathrm{~kg} \mathrm{~N} / \mathrm{ha}$ tai niitä ei lannoitettu lainkaan. Osa lannoitti keinolannoitteilla, osa karjanlannalla. Palkokasvien seuraavalle kasville jättämä typpi huomioitiin ja lannoitustasoja alennettiin niillä lohkoilla, joilla oli edellisvuonna viljelty palkokasveja. Yhdellä tilalla hyvänä kokemuksena pidettiin säiden salliessa syysvehnän kylvöä samana syksynä härkäpavun korjuun jälkeen. Tällöin härkäpavun maahan sitoma typpi saatiin jo syksyllä käyttöön.

Valkuaiskasvit toivat monipuolisuutta viljelykiertoihin ja usealla tilalla maan rakenteen todettiin parantuneen palkokasvien viljelyn myötä. Muutokset maan rakenteessa näkyivät erityisesti maan kuohkeutumisena sekä multavuuden ja mururakenteen lisääntymisenä. Yhtenä esimerkkinä maan rakenteen parantumisena mainittiin että lierot olivat palanneet peltoon. Oli myös kokemuksia siitä, ettei vaikutuksia maan rakenteeseen ollut. Osalla tiloista syynä saattoi olla se, että palkokasvien viljelyä oli harjoitettu vasta lyhyen aikaa, eivätkä vaikutukset välttämättä vielä näkyneet. Härkäpapua pidettiin hyvänä välikasvina viljoille. Erityisesti monokulttuurissa se toi toivottavaa kasvivaihtelua ja katkaisi viljojen tautipainetta. 
Hernettä, härkäpapua ja sinimailasta viljeltiin pääasiassa savi-, hietasavi- ja hietamailla. Kokemukset härkäpavun viljelystä eloperäisillä mailla eivät olleet hyviä. Ongelmia oli ollut erityisesti sadonkorjuussa märkinä vuosina. Sinimailasta puolestaan ei suositeltu viljeltäväksi raskailla, tiukoilla savimailla. Herneen ja härkäpavun viljelyssä metsänreunat koettiin ongelmallisiksi, koska varjostus myöhästytti sadon tuleentumista ja pienensi satoa. Sinimailasta ei kannata kylvää märille, veden vaivaamille lohkoille, koska niillä se ei menesty. Poutivilla lohkoilla ja kuivilla rinnemailla sinimailanen puolestaan on kokeilemisen arvoinen kasvi, sillä syvän juurensa ansiosta se saa vettä ja ravinteita syvältäkin pellosta ja menestyy kuivissakin olosuhteissa.

Härkäpapua ja hernettä oli viljelty sekä puitavaksi että säilörehuksi ja sinimailasta säilörehuksi. Herneen säilönnästä oli kokemuksia kuivattuna ja murskesäilöttynä. Härkäpavun ja herneen viljelyä oli tehty sekä puhdas- että seoskasvustona. Seoksena härkäpapua oli viljelty sekä vehnän että kaura-rehuherneseoksen kanssa, kun taas hernettä oli viljelty kauran kanssa. Yhden tilan kokemukset härkäpavun viljelystä vehnän kanssa eivät olleet hyvät. Ongelmaksi oli muodostunut vehnän huono kestävyys rikkakasviäestyksessä ja myöhäinen puintiajankohta, joka aiheutti vehnällä varisemistappioita. Lisäksi härkäpapu varjosti tehokkaasti vehnää, jonka seurauksena vehnän kasvu jäi vähäiseksi ja satoa tuli vähän.

Sinimailaskasvustoja oli kokeiltu perustaa keskikesällä ja syksyllä, mutta ne eivät olleet onnistuneet. Perustamista keväällä ja seoskasvustona suojakasvin kanssa pidettiinkin varmimpana. Sinimailassiemenen ymppäys todettiin välttämättömäksi. Sinimailasnurmen perustamisvuonna kasvuston tallausta tulee erityisesti välttää, koska se saattaa aiheuttaa mailasen häviämistä tallatuista kohdista. Tallauksen vähentämiseksi suojakasvin korjuuta vihantana tai kokoviljasäilörehuna kannattaa harkita. Typpilannoitustaso tulee pitää kohtuullisena suojaviljan lakoutumisen ehkäisemiseksi.

Kasvinsuojelutoimista oli vaihtelevia kokemuksia. Osa oli tehnyt kasvinsuojeluruiskutuksia, osa ei, osalla kasvinsuojelu oli tuottanut toivottuja tuloksia, osalla ei. Kasvinsuojelun yhtenä suurimpana haasteena pidettiin sitä, että sopivia kasvinsuojeluaineita oli niukasti saatavilla. Rikkakasviäestysten toimivuudesta oli vaihtelevia kokemuksia. Syinä saattoi olla äestyksen ajankohta, sääolosuhteet ja lohkon rikkakasvitilanne. Joillakin tiloilla kasvitauteja ja rikkakasveja ei pidetty ongelmana, eikä niiden vuoksi oltu jouduttu tekemään torjuntatoimenpiteitä. Nämä tilat olivat tyytyväisiä saatuihin säästöihin kasvinsuojeluaineissa.

Osalla valkuaiskasveista, erityisesti härkäpavulla, pitkä kasvukausi ja sateiset korjuukelit puinnin ja kuivauksen kannalta koettiin viljelyn riskinä. Toisaalta todettiin myös, että pitkä kasvukausi tuo joustoa viljelyyn, kun härkäpapu on ensimmäisiä kylvettäviä ja viimeisiä korjattavia kasveja. Lisäksi mahdollisuus korjata härkäpapu kokoviljasäilörehuksi pienensi korjuuseen liittyvää riskiä. Herneen viljelyn haasteena mainittiin erityisesti sen lakoutumisherkkyys. Tosin tätä voitiin vähentää viljelemällä hernettä seoskasvustona viljan kanssa ja kiinnittämällä lajikevalinnassa huomiota sen korrenlujuuteen. Tällöin vilja toimii herneen tukikasvina ja ehkäisee lakoutumista.

Härkäpavun puintikokemukset vaihtelivat sen mukaan millaista puitava kasvusto oli. Kasvuston ollessa pystyssä ja hyvin tuleentunutta ei puinnin kanssa ollut ongelmia. Puimurin säädöissä hyvänä todettua olivat alhaiset kelan kierrokset, varstasilta lähes kokonaan auki, seulat täysin auki ja tuuli kovalle. Puinnin haasteena pidettiin alimpien papujen sijaintia lähellä maanpintaa, jolloin puimurin pöytä jouduttiin laskemaan hyvin alas. Lakoontuneen härkäpavun puintia pidettiin hankalana ja sen todettiin lisäävän satotappioita. Lisäksi märkää härkäpapua puitaessa puimurin kohlimia ja seuloja joutui puhdistamaan usein, mikä hidasti puintia ja lisäsi työkustannuksia. Yksi ratkaisu märän syksyn puintiongelmiin voisi olla pakkasten odottaminen. Osalla tiloista oli onnistuneita kokemuksia härkäpavun puinnista pakkasella, kunhan kasvusto on lumeton ja pakkasta on yli -5 astetta. Mikäli hernekasvusto on lakoontunutta, on tärkeää että kasvusto on puitaessa valmista ja herne riittävän kuivaa, jotta puinti onnistuu.

Härkäpavun varastointikosteus vaihteli 13-17 \%:n välillä riippuen käyttötarkoituksesta. Osa viljelijöistä oli jäähdyttänyt härkäpapua kuivauksen aikana niin, että ensin kuivaus oli tehty miedolla, noin 50 asteen lämmöllä noin $20 \%$ :n kosteuteen, sitten seisotettu vuorokausi ja tämän jälkeen kuivattu varastokosteuteen. Vaiheittaisella ja miedolla kuivauslämmöllä tehty kuivausta pidettiin härkäpavun kannalta hyvänä, sillä se estää papujen halkeilua. Herneen kuivauksessa käytettiin pääasiassa hidasta kuivausta ja sopivana varastokosteutena pidettiin 14-15\%. Tätä kuivemmaksi ei rehukäyttöön tarkoitettua hernettä viljelijöiden mielestä kannata kuivata, koska kuivempana ja sen seurauksena kovempana se saattaa vaikeuttaa jauhatusta. Märän härkäpavun kuivaus koettiin haasteelliseksi. Ensimmäinen hankaluus tuli siinä, että märän härkäpavun saaminen kärrystä pois voi olla ongelmallista. Osa tiloista oli 
ratkaissut ongelman laittamalla kärryn pohjalle kerroksen kuivattua härkäpapua tai viljaa. Erään viljelijän neuvo oli, että kuivuriin kipattaessa kuivurin kierron tulee olla jo päällä. Kokemuksena herneen murskesäilönnästä todettiin, että haastavinta oli saada se murskattua. Kovan herneen murskaaminen vaati paljon tehoja.

Suurin osa tiloista ajoitti sinimailasnurmen ensimmäisen korjuun timotein korjuuajankohdan mukaan, toinen korjuu ajoittui kukintavaiheeseen ja kolmas korjuu tehtiin viimeistään syyskuun lopussa. Kolmannen sadon korjuu tulisi ajoittaa niin, että kasvusto ehtii kasvaa n. $20 \mathrm{~cm}$ :n pituuteen. Jos syksyn korjuuolosuhteet ovat märät, kokemukset olivat osoittaneet, että kolmas sato kannattaa jättää ennemmin korjaamatta kuin mennä sotkemaan märille pelloille. Märkien peltojen tallaaminen lisää riskiä, että mailanen häviää kasvustosta. Hyvänä sinimailasen niittokorkeutena pidettiin 8-10 cm:n sänkeä. Perusteena oli rehun hygieenisyys, jolloin multaa ei joudu rehun sekaan ja kokemukset että odelman kasvuunlähtö oli nopeampaa, kun sängen korkeus oli yli $5 \mathrm{~cm}$. Sinimailassäilörehun säilönnässä oli käytetty sekä happopohjaisia säilöntäaineita että biologisia, ja molemmilla rehu oli säilynyt hyvin.

Härkäpavun ja herneen satotasot vaihtelivat paljon. Tavanomaisessa viljelyssä härkäpavun satotasot olivat $1500-4800 \mathrm{~kg}$ ja luomutuotannossa $1000-3800 \mathrm{~kg}$. Herneen sadot vaihtelivat puhtaassa hernekasvustossa 2000-3000 kg:n välillä ja seoskasvustossa viljan kanssa 1600-4100 kg. Satotasojen suurta vaihtelua pidettiinkin yhtenä härkäpavun ja herneen suurimmista ongelmista. Sinimailasen oli todettu nostavan satotasoja, rehun raakavalkuaispitoisuutta ja maittavuutta, mutta energia-arvot olivat alhaisemmat nurmisäilörehuun verrattuna.

\section{Kokemuksia valkuaiskasvien käytöstä nautojen ruokinnassa}

Kokemukset herneen, härkäpavun ja sinimailasen käytöstä nautojen ruokinnassa olivat hyviä. Ne olivat maittavia rehuja ja sekä syönnin että tuotosten lisääntymistä oli havaittu. Hyvänä asiana pidettiin myös niiden monipuolisuutta niin rehukäytössä kuin rehunteossakin. Lisäksi niillä oli pystytty korvaamaan ostovalkuaisrehuja, mikä näkyi alentuneina ostorehukustannuksina.

Härkäpavun käyttömäärät lypsävien lehmien ruokinnassa vaihtelivat $0,5-2$ kilon välillä. Herneen osuus väkirehussa vaihteli 10-20 \%:n välillä. Härkäpavun ja herneen lisäksi tiloilla käytettiin teollisia valkuaisrehuja, rypsirouhetta, rypsipuristetta ja valkuaismelassia. Lihanautatiloilla oli kotoisista valkuaisrehuista käyttökokemuksia vain härkäpavusta. Kokemukset olivat pääosin hyviä. Tosin eräällä tilalla oli havaittu härkäpavun löystyttävän sontaa, mikä saattaa aiheuttaa lantaisuusongelmia eläimille. Sinimailasen ollessa ruokinnassa todettiin, että silloin tulee kiinnittää erityisesti huomiota riittävään kuidun ja energian saantiin. Korkean kalsium-pitoisuutensa vuoksi sinimailanen ei sovi ummessa oleville lehmille.

Härkäpavun jauhatuksessa koettiin olevan jonkin verran haasteita johtuen pavun kovuudesta. Osalla tiloista todettiin, että myllyjen ongelmana oli liian vähäinen teho, jolloin osa pavuista jäi kokonaisiksi. Härkäpavusta tehdyn säilörehun käytössä seosrehuruokinnassa korostettiin, että seos pitää sekoittaa huolellisesti, jotta härkäpavun korsi ei jää liian pitkäksi. Härkäpapusäilörehun käytön ongelmina mainittiin sen matala kuiva-ainepitoisuus, mikä tekee rehusta painavaa käsitellä ja saattaa aiheuttaa jäätymistä talvella.

\section{Tilojen väliselle yhteistyölle ja lisätiedolle on tarvetta}

Tilojen väliselle yhteistyölle todettiin olevan tilausta, sillä valkuaisrehuille on nautatiloilla kysyntää, eivätkä kaikki karjatilalliset viljele valkuaiskasveja omalla tilallaan, tai viljely on riittämätöntä. Kasvinviljelytilalla valkuaiskasvit monipuolistavat viljelyä, parantavat peltojen viljelyominaisuuksia ja tuovat vaihtoehtoja viljelykiertoon.

Osalla tiloista oli kokemusta tilojen välisestä yhteistyöstä valkuaiskasvien viljelyssä ja käytössä ruokinnassa. Osa tiloista osti valkuaisrehua toisilta tuottajilta. Tähän oli päädytty $\mathrm{mm}$. sen vuoksi, että käyttömäärät olivat niin vähäiset, ettei viljely omalla tilalla ollut mielekästä, mutta ruokinnassa haluttiin kuitenkin suosia kotimaisia valkuaisrehuja. Myös kotoisten valkuaisrehujen hinnoittelu vaikutti niiden käyttöön. Hintojen ollessa kilpailukykyisiä muihin valkuaisrehuihin nähden niiden käyttö oli taloudellisestikin perusteltua. Joillain tiloilla oma peltopinta-ala ei riittänyt kaiken tarvittavan valkuaisrehun tuottamiseen ja tällöin yhteistyö muiden tilojen kanssa oli tarpeen.

Tilojen välisenä yhteistyönä viljelijät pitivät tärkeänä myös tiedon ja kokemusten vaihdon. Tietoa ja kokemuksia tulisi jakaa niin valkuaiskasvien viljelystä kuin käytöstä ruokinnassa. Tärkeänä pidettiin sekä hyvien että huonojen kokemusten jakamista, joista molemmista voi oppia. 
Neuvojien suunnalta toivottiin kannustusta valkuaiskasvien viljelyyn ja rehukäyttöön. Ja sen lisäksi, että viljelijöiden tietotaitoa valkuaiskasveista tulee lisätä, sama pätee myös neuvojiin. Lisäksi viljelijöitä tulee kannustaa teettämään nykyistä enemmän rehuanalyysejä myös kotoisista valkuaisrehuista niiden käytön optimoimiseksi ruokinnassa.

Ruokinnassa valkuaiskasvien käytön haasteena mainittiin melko vähäinen kotimaisen tutkimustiedon saatavuus. Erityisesti eri valkuaisrehujen käyttömääristä ruokinnassa ja vaikutuksista tuotantotuloksiin kaivattiin lisätietoa.

\section{Johtopäätökset}

Valkuaisomavaraisuutta on mahdollista nostaa niin kasvinviljely- kuin kotieläintiloilla. Suomessa viljeltävät valkuaiskasvit tarjoavat tähän monia mahdollisuuksia. Tilojen välinen yhteistyö voisi olla yksi ratkaisu edistää valkuaisomavaraisuutta. Kaikki karjatilalliset eivät viljele valkuaiskasveja omalla tilallaan tai viljely on riittämätöntä. Kasvinviljelytiloilla puolestaan valkuaiskasvit ovat hyviä viljojen välikasveja. Palkokasveja viljelemällä voidaan saada kustannussäästöjä ostolannoitteissa ja -rehuissa. Lisäksi niillä on maan kasvukuntoa parantavia vaikutuksia, ne monipuolistavat viljelykiertoa ja tuovat joustoa korjuuaikaan. Kotoisten valkuaiskasvien käytöstä ruokinnassa on saatu hyviä kokemuksia. Ne ovat maittavia ja tuotantotuloksissa on havaittu positiivisia vaikutuksia. Vaikka viljelijät olivat pääosin tyytyväisiä valkuaiskasvien viljelyyn ja rehukäyttöön, kehitettävääkin löytyi. Erityisesti kasvien viljelyvarmuuteen ja satoisuuteen toivottiin parannusta. Tällä on vaikutusta sekä tuotannon kannattavuuteen että ruokinnan suunnitteluun. Tähän voisi yhtenä ratkaisuna olla lajikevalikoiman lisääntyminen. Lisätutkimukselle on myös tilausta, sillä tietoa valkuaiskasvien viljelystä ja käytöstä ruokinnassa tarvitaan, jotta niiden käyttö lisääntyisi.

\section{Kirjallisuus}

Huusela-Veistola, E., Jalli, H., Jalli, M., Koikkalainen, K., Kymäläinen, M., Känkänen, H., Lemola, R., Lizarazo, C., Nykänen, A., Sipiläinen, T., Stoddard, F. \& Vanhatalo, A. 2012. Typpi- ja valkuaisomavaraisuuden lisääminen palkokasveja tehokkaasti hyödyntämällä. Arja Nykänen (toim.) MTT Raportti 59. https://jukuri.luke.fi/handle/10024/438264 83 s.

Huuskonen, L. 2014. Lihanautojen valkuaisrehuruokinta. Hämeen ammattikorkeakoulu. Maaseutuelinkeinojen koulutus. Opinnäytetyö. http://urn.fi/URN:NBN:fi:amk-2014061813132 27 s.

Kasvala, P. 2015. Sinimailasen viljelykokemuksia - Onnistumisia ja epäonnistumisia. Hämeen ammattikorkeakoulu. Maaseutuelinkeinojen koulutus. Opinnäytetyö. http://urn.fi/URN:NBN:fi:amk-201505229622 36 s.

Kaukovirta-Norja, A., Leinonen, A., Mokkila, M., Wessberg, N \& Niemi, J. 2015. Tiekartta Suomen proteiiniomavaraisuuden parantamiseksi. Mirja Mokkila (toim). http://www.vtt.fi/inf/pdf/visions/2015/V6.pdf 69 s.

Lehtinen, S. 2014. Härkäpavun viljely ja käyttö lypsylehmien ruokinnassa. Hämeen ammattikorkeakoulu. Maaseutuelinkeinojen koulutusohjelma. Opinnäytetyö. http://urn.fi/URN:NBN:fi:amk-201402162350 46 s. Mikkola, A. 2014. Herneen viljely ja käyttö lypsylehmien ruokinnassa. Hämeen ammattikorkeakoulu. Maaseutuelinkeinojen koulutusohjelma. Opinnäytetyö. http://urn.fi/URN:NBN:fi:amk-201402172380 $31 \mathrm{~s}$. Peltonen-Sainio, P. 2013. Kotimaisen valkuaisomavaraisuuden parantaminen globaalimuutosten paineessa. OMAVARA 2010-2013, loppuraportti. http://jukuri.mtt.fi/handle/10024/481010 $17 \mathrm{~s}$.

Stoddard, F., Lizarazo, C., Mäkelä, P. \& Nykänen, A. 2010. New annual legume crops for Finnish conditions. Teoksessa: Anneli Hopponen (toim.) Maataloustieteen Päivät 12.-13.1.2010. Suomen maataloustieteellisen seuran julkaisuja no. 27. 